\title{
Does MDR1 promoter methylation affect temozolomide resistance? A clinical study in patients with glioblastoma
}

\author{
MDR1 promoter metilasyonu temozolomid direncini etkiler mi? Glioblastomlu hastalarda \\ klinik çalışma
} Yahya Efe Güner, Eyüp Bayatı, Aslıhan Kurt Kızıldoğan, Derya Gökmen, Veysel Yüksek, Filiz
Taşpınar, Bora Tetik, Mehmet Taşpınar, Hasan Çağlar Uğur

Gönderilme tarihi:23.12.2021

Kabul tarihi:21.02.2022

\section{Abstract}

Purpose: The multidrug resistance 1 (MDR1) gene expression and its epigenetic status may be an important factor in the chemotherapeutic resistance of glioblastoma (GB). The aim of this study was to analyze the effect of the MDR1 promoter methylation status on GB tumor tissue related to patient survival, chemotherapy resistance, and recurrence of the disease.

Materials and methods: Thirty-six patients underwent surgery for GB at the Neurosurgery Department of Ankara University School of Medicine. The patients' clinical information and the MDR1 methylation status of the tumor tissues were compared to determine the effects on patient survival, chemotherapy resistance, and tumor recurrence.

Results: Patients with MDR1 methylated GB had statistically significantly $(p<0.001)$ shorter survival times. Early recurrence was detected in $25 \%$ of the patients with unmethylated tumor tissues and in $39.3 \%$ with hemimethylated tumor tissues.

Conclusion: Instead of using the standard chemotherapeutics in all the patients with GB, tissue-specific medications must be chosen while taking into consideration the epigenomic characteristics and expression status of the tumor because of the genetic heterogeneity of GB. This is the first study to show the association between MDR1 promoter methylation and the clinical data of GB in the literature.

Key words: Chemotherapeutic resistance, glioblastoma, methylation, multidrug resistance 1.

Guner YE, Bayatli E, Kurt Kizildogan A, Gokmen D, Yuksek V, Taspinar F, Tetik B, Taspinar M, Ugur HC. Does MDR1 promoter methylation affect temozolomide resistance? a clinical study in patients with glioblastoma. Pam Med J 2022;15:547-554.

Öz

Amaç: Çoklu ilaç direnci 1 (MDR1) gen ekspresyonu ve epigenetik durumu, glioblastomun (GB) kemoterapötik direncinde önemli bir faktör olabilir. Bu çalışmanın amacı, MDR1 promoter metilasyon durumunun, hastanın sağkalımı, kemoterapi direnci ve hastalığın tekrarlaması ile ilgili olarak GB tümör dokusu üzerindeki etkisini analiz etmektir.

Gereç ve yöntem: Ankara Üniversitesi Tıp Fakültesi Beyin Cerrahisi Anabilim Dalı'nda GB tanısı ile ameliyat edilen 36 hastanın verileri incelendi. Hastaların klinik bilgileri ve tümör dokularının MDR1 metilasyon durumu, hastanın sağkalımı, kemoterapi direnci ve tümör nüksü üzerindeki etkilerine yönelik karşılaştırıldı.

Bulgular: MDR1'nin metile olduğu GB'li hastalarda istatistiksel olarak anlamlı $(p<0,001)$ daha kısa sağkalım süreleri saptandı. Metile tümör dokusu olan hastaların \%25'inde ve hemi-metile tümör dokusu olan hastaların $\% 39,3$ 'ünde erken rekürrens saptandı.

Sonuç: GB'li tüm hastalarda standart kemoterapötikleri kullanmak yerine, GB'nin genetik heterojenliği nedeniyle tümörün epigenomik özellikleri ve ekspresyon durumu dikkate alınarak dokuya özgü ilaçlar seçilmelidir. Bu, literatürdeki MDR1 promoter metilasyonu ile GB'nin klinik verileri arasındaki ilişkiyi gösteren ilk çalışmadır.

Yahya Efe Güner, Ass. Prof. Instructor, Department of Neurosurgery, Faculty of Medicine, Yuksek Ihtisas University, Ankara, Turkey, e-mail: yahyaefeguner@gmail.com (https://orcid.org/0000-0001-9660-5941) (Corresponding Author)

Eyüp Bayatı, M.D. Instructor, Department of Neurosurgery, Faculty of Medicine, Ankara University, Ankara, Turkey, e-mail: e.bayatli@hotmail. com (https://orcid.org/0000-0001-6246-4247)

Aslıhan Kurt Kızıldoğan, PhD, Assoc. Prof. Department of Agricultural Biotechnology, Faculty of Agriculture, Ondokuz Mayıs University, Samsun, Turkey, e-mail: aslihankurt@gmail.com (https://orcid.org/0000-0002-9323-0993)

Derya Gökmen, PhD, Assoc. Prof. Department of Biostatistics, Faculty of Medicine, Ankara University, Ankara, Turkey, e-mail: dgokmen2001@ yahoo.com (https://orcid.org/0000-0001-6266-3035)

Veysel Yüksek, PhD, Department of Medical Laboratory Techniques, Özalp Regional High School, Yuzuncu Yil University, Van, Turkey, e-mail: veyselyuksek@yyu.edu.tr (https://orcid.org/0000-0003-0361-2275)

Filiz Taşpınar, PhD, Department of Physiology, Faculty of Medicine, Aksaray University, Aksaray, Turkey, e-mail: flzozkaya@gmail.com (https:// orcid.org/0000-0003-3780-4021)

Bora Tetik, MD, Instructor, Department of Neurosurgery, Faculty of Medicine, Inonu University, Malatya, Turkey, e-mail: drbora_tetik@hotmail. com (https://orcid.org/0000-0001-7696-7785)

Mehmet Taşpınar, PhD, Prof. Department of Medical Biology, Faculty of Medicine, Aksaray University, Aksaray, Turkey, e-mail: mtaspinartr@ gmail.com (https://orcid.org/0000-0002-7598-2665)

Hasan Çağlar Uğur, MD, PhD, Prof. Department of Neurosurgery, Faculty of Medicine, Ankara University, Ankara, Turkey, e-mail: hasanugur2001@hotmail.com (https://orcid.org/0000-0003-3728-4599) 
Anahtar kelimeler: Kemoterapötik direnç, glioblastoma, metilasyon, çoklu ilaç direnci geni 1.

Güner YE, Bayatı E, Kurt Kızıldoğan A, Gökmen D, Yüksek V, Taşpınar F, Tetik B, Taşpınar M, Uğur HÇ. MDR1 promoter metilasyonu temozolomid direncini etkiler mi? Glioblastomlu hastalarda klinik çalışma. Pam Tıp Derg 2022;15:547-554.

\section{Introduction}

Glioblastoma (GB) is the most malignant and frequent brain tumor $(5 / 100.000)$ in adults. GB accounts for $12-15 \%$ of all intracranial tumors and $50-60 \%$ of astrocytic tumors. Despite the advanced treatments, the mean patient survival from the disease is 14.6 months. Only $10 \%$ of patients survive after 2 years [1]. In newly diagnosed GB tumors, environmental factors, life habits, and genetic risk factors cannot be determined substantially.

The current GB treatment is based primarily on maximal surgical excision, followed by chemotherapy and radiotherapy [2, 3]. Moreover, chemotherapy/drug resistance is a major issue in such malignant diseases. The cellular function of adenosine triphosphate (ATP)-binding cassette (ABC) transporter family proteins is an important mechanism that may play a role in GB treatment [4]. ABC transporter family proteins, including $P$-glycoprotein ( $P$ $\mathrm{gp}), \mathrm{ABC}$ subfamily $\mathrm{B}$ member 1 and multidrug resistance (MDR1) pump drugs and toxins into the extracellular space, decreasing the intracellular drug load. Experimental studies on drug transportation have shown that twosided transfer of P-gp causes a decrease in intracellular drug concentration and an increase in extracellular space drug efflux [5]. Clinically, MDR1-related drug resistance forms a wellknown MDR mechanism [6]. MDR1 expression can be changed via different epigenetic mechanisms such as methylation, acetylation, and phosphorylation. In vitro studies have shown that MDR1 expression plays a role in the mechanism of action of temozolomide (TMZ) in addition to DNA repair mechanisms [7].

In this study, we aimed to investigate the MDR1 promoter methylation status in patients treated with TMZ and the role of its methylation on survival. No previous studies investigated the likely relationship between MDR1 promoter methylation and $T M Z$ resistance in GB. This study provides the first assessment of MDR1 gene promoter methylation in patients with GB.

\section{Materials and methods}

\section{Study groups}

The study was conducted after approval by the Clinical Ethical Committee of Ankara University. The study group consisted of patients with a central nervous system mass pathologically approved as GB who underwent operation between January 2014 and January 2016 in the Ankara University Neurosurgery Department. Written informed consent was obtained from all the patients or their families. None of the patients has received any therapy such as chemotherapy and radiotherapy prior to surgery and sample collection.

Tumor tissues and peripheral blood samples (as a control for each patient) were collected from all patients. Tumor tissue sampling was achieved in a way that did not hinder the pathological analysis. The extent of surgical tumor resection was defined as gross total resection for cases in which the entire tumor was removed; and subtotal resection when a greater portion of the tumor was left. Blood sampling was achieved during preoperative blood examination to avoid any additional invasive procedures.

\section{Genomic DNA extraction}

The tumor tissue sample from the patients was cleaned from the vascular and necrotic regions in the laminar cabin under sterile conditions and then frozen and stored. The tissue and peripheral blood samples were stored at $-80^{\circ} \mathrm{C}$ and $-20^{\circ} \mathrm{C}$ until extraction of genomic DNA, respectively. Genomic DNA was isolated from the primary frozen tumor tissues and peripheral blood samples by using the PureLink Genomic DNA Kit (Life Technologies, K182002) in accordance with the manufacturer's instruction. The purity and amount of obtained genomic DNA were measured with a spectrophotometer according to a $260: 280$ ratio. 


\section{Bisulfite modification and methylation- specific polymerase chain reactions}

Bisulfate modification was performed with 1- $\mu$ g genomic DNA using a DNA modification kit (EZ DNA Methylation-Gold). Bisulfate modification is based on the presence of a methylated cytosine base on genomic DNA. All methylated cytosine bases are not converted to uracil bases after modification, but methylated cytosines are converted to uracil bases.

To determine the MDR1 gene methylation in modified DNA, methylation-specific polymerase chain reaction (MS-PCR) was performed using specific primer pairs for the MDR1 gene. The specific primers for the MDR1 gene were used to show the methylation status of the MDR1 gene in PCR. The reaction mix of MS-PCR contained $25-\mu \mathrm{l} 2 \mathrm{X}$ reaction buffer (Zymo Taq), 0.5- $\mu \mathrm{l}$ dNTP (0.25 mM Zymo Taq), 0.4- $\mu$ forward and reverse primers for $U$ or $M$ status $(10 \mu \mathrm{M}), 60-n g$ template DNA, 0.4- $\mu \mathrm{l}$ Taq polymerase $(5 \mathrm{U} / \mu \mathrm{l})$, and additional $\mathrm{dH}_{2} \mathrm{O}$ up to a $50-\mu \mathrm{l}$ mix reaction volume.
The primers used in the MS-PCR were U-Forward: 5' GGG TGT GGG TTG AGT ATA GTT GTT TT, U-Reverse: 5' CCA ACT TTA CAT ACC CCT ACC TCA CA for unmethylation status, M-Forward: 5' GGG CGT GGG TTG AGT ATA GTC GTT TC, and M-Reverse: 5' CGC TCC TTAAAA CAA CCA CCAAAA CG for methylation status.

The reaction conditions for both primer sets were as follows: initial denaturation at $95^{\circ} \mathrm{C}$ for $10 \mathrm{~min}$, followed by 40 cycles of denaturation at $95^{\circ} \mathrm{C}$ for $45 \mathrm{~s}$, annealing at $57.8^{\circ} \mathrm{C}$ for $45 \mathrm{~s}$, and extension at $72^{\circ} \mathrm{C}$ for $45 \mathrm{~s}$, and final extension at $72^{\circ} \mathrm{C}$ for $5 \mathrm{~min}$. The PCR products were visualized on $2 \%$ agarose gels and stained with ethidium bromide under ultraviolet light (Figure 1).

The presence of a $240-b p$ band in the lane marked $U$ indicates an unmethylated MDR1 gene promoter, while the presence of a 230 $\mathrm{bp}$ band in the lanes marked $\mathrm{M}$ indicates a methylated MDR1 gene promoter (Figure 1).

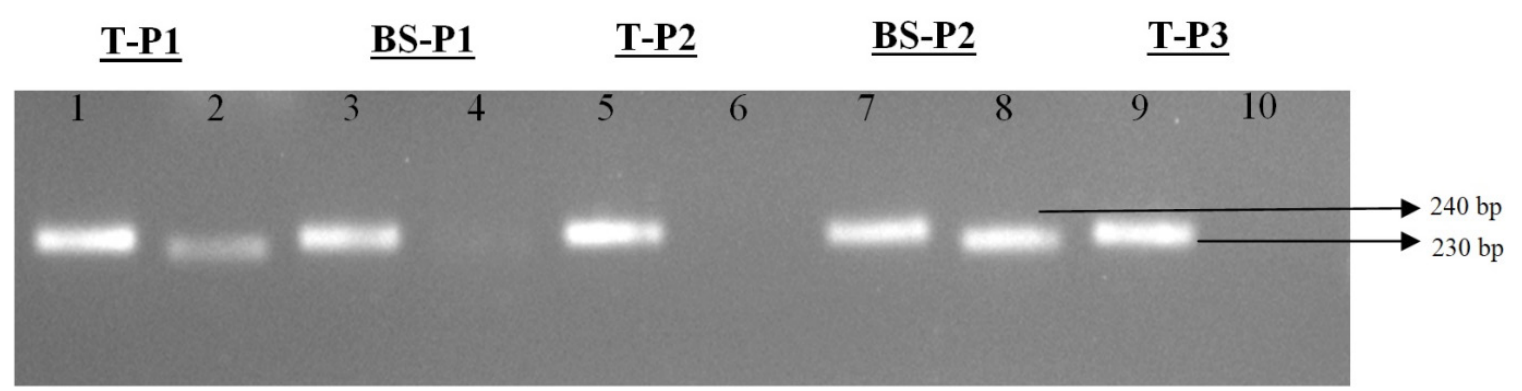

Figure 1. The unmethylated band of the MDR1 gene was detected in the tumor tissue $(\mathrm{T})$ and blood sample (BS) DNA of Patient 1. The methylated band of the MDR1 gene was detected in the tumor tissue of Patient 1. Patient 2 has a UU status in tumor tissue and UM status in BS. P3 has a UU status in tumor tissue, and no methylation status could be detected in the BS sample. The 240-and 230-bp bands indicate the $U$ and $M$ statuses of the MDR1 gene promoter, respectively

T: Tumor, P: Patient, BS: Blood sample

\section{Statistical analyses}

The SPSS 11.5 package program was used to evaluate the data obtained in the study. The methylation rates in tumorous tissues and peripheral blood were performed with the McNemar test developed to compare categorical data in the dependent groups. The gene methylation values obtained as continuous measurements were evaluated using a $t$ test for dependent groups (paired $t$ test). While the results of the categorical variables were summarized with frequency distributions and proportions, mean \pm SD and median (range) were used as descriptive statistics for continuous variables. The statistical significance level was selected as $p<0.05$ for all comparisons and hypothesis tests. 


\section{Results}

Detailed clinical data and MDR1 methylation results were obtained in 36 patients whose MDR1 gene methylations were investigated. The mean age of the patients was $55.4 \pm 16.8$ years (median, 54.5 years (range, 20-82 years)), and 10 patients were female and 26 were male. The mean follow up was 15.6 months (range, 8-24 months). The mean survival of all the patients was $476 \pm 61$ days. Table 1 presents the demographic and clinical data of the study population.

Table 1. Major clinical data of the patients included in our study

\begin{tabular}{|c|c|}
\hline & All patients $(n=36)$ \\
\hline \multicolumn{2}{|l|}{ Age at diagnosis, years } \\
\hline Median (range) & $54.5(20-82)$ \\
\hline \multicolumn{2}{|l|}{ Sex } \\
\hline Male (\%) & $26(72.2 \%)$ \\
\hline Female (\%) & $10(27.7 \%)$ \\
\hline \multicolumn{2}{|l|}{ Tumor location - region } \\
\hline Frontal (\%) & $11(30.5 \%)$ \\
\hline Parietal (\%) & $11(30.5 \%)$ \\
\hline Temporal (\%) & $7(19.4 \%)$ \\
\hline Occipital (\%) & $6(16.6 \%)$ \\
\hline Other $(\%)$ & $1(2.7 \%)$ \\
\hline \multicolumn{2}{|l|}{ Surgery } \\
\hline Gross total resection $(80-99 \%)$ & $29(80.5 \%)$ \\
\hline Subtotal $(50-80 \%)$ & $7(19.5 \%)$ \\
\hline \multicolumn{2}{|l|}{ First-line Therapy } \\
\hline Radiotherapy (\%) & $5(13.8 \%)$ \\
\hline Radiotherapy and concomitant temozolomide (\%) & $31(86.1 \%)$ \\
\hline
\end{tabular}

The MDR1 promoter methylation was determined as UU (both alleles unmethylated) in $4(11.1 \%)$ and $\mathrm{MM}$ (both alleles methylated) in 4 $(11.1 \%)$ of the 36 patients included in the study, and UM (heterogeneous methylation status) in the remaining 28 tumor tissues (77.8\%). UM was detected in the blood samples of two of the 4 tumor samples with UU methylation status. In addition, MDR1 methylation was not detected in 11 blood samples from 28 patients whose MDR1 gene was detected as UM in tumor tissues. MDR1 promoter methylation was detected in 32 $(88.8 \%)$ tumor tissues when evaluated on the basis of methylation (Table 2).
In all the patients, maximum safe surgical resection was followed by radiotherapy (RT; 60 Gy in 30 fractions) plus concurrent TMZ (75 mg/ $\mathrm{m}^{2} /$ day for 6 weeks) and then six maintenance cycles of TMZ chemotherapy $\left(150-200 \mathrm{mg} / \mathrm{m}^{2} /\right.$ day for the first 5 days of a 28-day cycle) [8].

When the chemotherapeutic resistance development of the patients was evaluated on the basis of the MDR1 promoter methylation obtained from the tumor tissues, no significant relationship was found between chemotherapeutic resistance development and methylation status ( $p>0.05$; Table 3$)$. In addition,

Table 2. MDR1 promoter methylation numbers and percentages based on methylation

\begin{tabular}{llll}
\hline Sample Type & UU & UM & MM \\
Tumor Tissues & $4(11.1 \%)$ & $28(77.8 \%)$ & $4(11.1 \%)$ \\
Blood Samples & $1(5.0 \%)$ & $19(95.0 \%)$ & $0(0 \%)$ \\
\hline
\end{tabular}

UU: both unmethylated alleles; MM: both methylated alleles

UM: heterogeneous methylation status 
Table 3. Relationship between MDR1 promoter methylation and chemotherapeutic resistance in the patients' tumor sample

\begin{tabular}{|c|c|c|c|c|c|}
\hline & \multicolumn{5}{|c|}{ MDR1 Methylation status of tumor samples } \\
\hline $\begin{array}{l}\text { Chemotherapeutic } \\
\text { resistance status }\end{array}$ & UU & UM & $\mathrm{MM}$ & Total & $p$ \\
\hline Resistant & 1 & 11 & 4 & 16 & $>005$ \\
\hline Nonresistant & 3 & 17 & - & 20 & \\
\hline $\begin{array}{l}\text { Survival time (days) } \\
\text { Mean (median } \pm \text { SD) }\end{array}$ & $\begin{array}{l}627.500 \\
(538.000 ; \pm 105.004)\end{array}$ & $\begin{array}{l}500.541 \\
(524.000 ; \pm 69.871)\end{array}$ & $\begin{array}{l}111.250 \\
(75.000 ; \pm 53.827)\end{array}$ & - & $<0.001$ \\
\hline
\end{tabular}

UU: Both unmethylated alleles; MM: Both methylated alleles

UM: Heterogeneous methylation status

early recurrence was observed in all the patients in whom chemotherapeutic resistance was found. Early recurrence was detected in all 4 patients $(100.0 \%)$ with MM status, $11(39.2 \%)$ of the 28 patients with UM status, and one $(25 \%)$ of the 4 patients with UU status.

When the MDR1 gene promoter methylation statuses of the patients were compared according to survival times, the survival time was $111.2 \pm 53$ days for those with $\mathrm{MM}$ with methylation in both alleles, $500.5 \pm 69$ days for those with UM status, and $627.5 \pm 105$ days for those with UU status. When the MDR1 methylation and survival times were compared, the effect of $M D R 1$ methylation status on survival was significant $(p<0.001)$. Early recurrence was observed in $100 \%$ of the patients with GB with MM status at clinical follow-up (Table 3).

\section{Discussion}

Although brain tumors constitute approximately $2 \%$ of the entire cancer burden, they cause significant morbidity, and the prognosis is still poor in gliomas, the most common type of central nervous system mass. The causes of GB are not clearly defined, no curative treatment has been established, and the average life span after diagnosis is still short $[3,9]$. Currently, in GB, the prognosis is still poor because of the distinctive resistance to radiotherapy and chemotherapy. Numerous genetic variations have been identified for GB, and therapeutic approaches based on molecular genetic mechanisms have been increasingly used nowadays. The development of alternative treatment approaches based on molecular genetic changes in GB is currently ongoing with great effort [10]. Various genetic and epigenetic changes are possible candidates for cancer treatment options. Many research studies have shown the characteristic features of GBs and indicated that GBs have a heterogeneous structure in every respect (clinical, genetic, and treatment) [1, 2, 11]. Therefore, a standard treatment without detailed personalized epigenetic and genetic profiling for such heterogeneous diseases may not be an accurate scientific approach for GB. Our presented study is the first to support the idea that MDR1 methylation profile may guide the management and individualized treatment of patients with glioblastoma regarding the documented association between MDR1 promoter methylation and the clinical data of GB patients.

Resistance to chemotherapeutic drugs may develop before and during treatment in GB. One of the mechanisms underlying this resistance may be various drug transporter proteins [11] that suggest MDR1. In the cells with high MDR1 expression, the intake of drugs into the cell is expected to be at a lower level as compared with the cells with low MDR1 expression levels. The $M D R 1$ expression level is reported to be high in some cancers [12-16]. In addition, intrinsic or acquired overexpression of the MDR1 gene has been detected $[17,18]$. However, when the central nervous system is considered to play a role in drug resistance, the importance of $\mathrm{P}$-gp is still controversial [11]. Drug-resistant gliomas show increased MDR1 expression without amplification as compared with sensitive ones [19].

One of the important mechanisms regulating MDR1 expression is DNA methylation. The gene expression decreases as a result of the methylation of $\mathrm{CpG}$ islets in the promoter region 
of the gene. The MDR1 promoter methylation has been detected in many types of cancer, and methylation may affect the prognosis of the disease and may even be a biomarker [20]. Quu et al. [21] associated MDR1 gene transcriptional inactivation with the progression and pathogenesis of neuroblastoma tumors as a result of a MDR1 methylation study in samples taken from patients with neuroblastoma. In our study, tumor progression was detected in patients with methylation. Our results were similar to the results of the study by Qui et al. [21].

The high MDR1 methylation rates (88\%, $83.3 \%$, and $80 \%$ ) were reported in the MDR1 gene methylation studies performed by Yegnasubramanian et al. [22], Bastian et al. [23], and Ellinger et al. [24] that evaluated cases with prostate cancer. In our study, a high methylation rate was found as in the abovementioned studies. Tahara et al. [12] reported that the high rate of MDR1 gene promoter methylation was detected in gastric cancers and that MDR1 methylation was effective in gastric cancer formation. In addition, Tahara et al. [12] stated that MDR1 methylation and decreased expression correlated with increased cell proliferation in cancer. In our study, a high rate of MDR1 methylation was detected in the patients with $\mathrm{GB}$, and early recurrence was detected in all the patients with methylation. In this respect, our results are in line with the results and suggestions of Tahara et al. [12] However, no studies have been reported regarding the role of MDR1 methylation in patients with GB. Therefore, in our study, the possible role of MDR1 promoter methylation in the prognosis of patients with GB was investigated. This is the first study investigating MDR1 gene promoter methylation in GB patients.

Von Bossanyi et al. [25] reported that P-gp expression may be associated with chemoresistance in gliomas and that $\mathrm{P}$-gp expression, evaluated by immunocytochemistry, is present even at different levels in high-grade brain tumors. Moreover, Von Bossanyi et al. [25] discussed that results reported in the literature are conflicting. Yokogami et al. [26] suggested that the P-gp levels decreased as the degree of malignancy increased in 16 series of untreated glioma cases and that P-gp level was inversely proportional to the tumor stage.
The aforementioned studies examined only the immunohistochemistry or RT-PCR of the MDR1 gene expression. Observing the MDR1 gene expression using immunohistochemistry or RTPCR may show results different from those in our study. In our study, the methylation status of MDR1 was examined with MS-PCR. Methylation status, which indicates low expression in a cell, is related to chemoresistance. We searched for the connection between methylation and prognosis in this study.

Abe et al. [27] reported that 9 patients with GB were evaluated and that multidrug resistance protein plays a more important role in chemotherapeutic resistance in gliomas than P-gp, P-gp expression may be lower in glioma tissues, and P-gp (MDR1) is more important in the transport of blood-brain barriers. Our study is the first to investigate the presence of MDR1 expression in glioma patients, along with clinical follow-up. As a result of our study, MDR1 promoter methylation was detected at a high rate of $88.8 \%$ in tumor tissues. This result is in line with the result of the study by Abe et al. [27.]

In a study conducted by Schaich et al. [7] in GBs, they reported that MDR1 expression might play a role in TMZ cytotoxicity and resistance. The presence of promoter methylation of any gene correlated with the low expression level in a cell. We detected high MDR1 methylation rates and no increased chemoresistance in our patients. Therefore, our results are similar to those of Schaich et al. [7]. In our study, MDR1 gene promoter methylation, which is thought to be responsible for the development of resistance to chemotherapeutics that may be present in patients with $G B$, was investigated. Our findings showed that MDR1 gene methylation might differ among patients with GB and even among different samples from the same individual. Our study shows that both tumor and blood samples from the same patient have different MDR1 methylation patterns. According to our literature review, the MDR1 methylation pattern has been shown for the first time to have a different status in the same patient. This is one of the examples that show the high genetic heterogeneity of GB. However, similar treatment modalities are applied in patients with GB with such genetic heterogeneity. In the treatment of $\mathrm{GB}$, individual cancer treatment should be applied after determining the genetic markers that can 
develop chemotherapeutic resistance, instead of applying the same treatments to patients with different genetic structures.

This study emphasizes the necessity of developing individual treatment modalities by considering genetic structures. Moreover, compared with clinical data such as MDR1 gene methylation investigated in GB tissues and patients' responses to recurrence, survival, and chemotherapy, the presence of MDR1 gene methylation worsened the prognosis in terms of survival and recurrence.

There are different genetic (1p/19q, MGMT expression, DNA repair genes, telomerase, etc) and epigenetic biomarkers (MGMT expression, microRNA, etc) to determine the TMZ chemoresistance [28] These molecular factors should be examined together in order to determine the $\mathrm{TMZ}$ resistance clearly.

This study has several limitations such as the small number of patients examined, clinical observation-based resistance evaluation, and the lack of determination of MDR1 expression with other techniques such as RT-PCR and immunocytochemistry. Also regarding the study period (2014-2016), none of the molecular parameters (like IDH, 1p/19q, etc) was routinely evaluated due to the former classification based on just histopathology. Owing to the short study period, we could not evaluate tumor tissues regarding molecular profiles that may add more information in respect to recurrence and survival.

The results of this study can be validated on MDR1 positive glioblastoma cancer stem cells (CSC). Because it is known that drug resistance of CSCs is caused by ABC transporter [11]. For this purpose, a side-population assay is required despite some limiting factors [11]. MDR1 positive human glioblastoma cancer stem cells can be used in further studies to elucidate the role of MDR1 in GB by using a side-population assay.

In conclusion, this is the first study to show the association between MDR1 promoter methylation and the clinical data of GB in the literature. MDR1 methylation profile may guide the management and individualized treatment of patients with GB.
Conflict of interest: No conflict of interest was declared by the authors.

\section{References}

1. Krakstad C, Chekenya M. Survival signalling and apoptosis resistance in glioblastomas: opportunities for targeted therapeutics. Mol Cancer 2010;9:135. https:// doi.org/10.1186/1476-4598-9-135

2. Adamson C, Kanu OO, Mehta Al, et al. Glioblastoma multiforme: a review of where we have been and where we are going. Expert Opin Investig Drugs 2009;18:10611083. https://doi.org/10.1517/13543780903052764

3. Rosell R, de Las Peñas R, Balaña C, et al. Translational research in glioblastoma multiforme: molecular criteria for patient selection. Future Oncol 2008;4:219-228. https://doi.org/10.2217/14796694.4.2.219

4. Endicott JA, Ling V. The biochemistry of P-glycoproteinmediated multidrug resistance. Annu Rev Biochem 1989;58:137-171. https://doi.org/10.1146/annurev. bi.58.070189.001033

5. Kartner N, Riordan JR, Ling V. Cell surface P-glycoprotein associated with multidrug resistance in mammalian cell lines. Science 1983;221:1285-1288. https://doi.org/10.1126/science.6137059

6. Feun LG, Savaraj N, Landy HJ. Drug resistance in brain tumors. J Neurooncol 1994;20:165-176. https:// doi.org/10.1007/BF01052726

7. Schaich M, Kestel L, Pfirrmann M, et al. A MDR1 (ABCB1) gene single nucleotide polymorphism predicts outcome of temozolomide treatment in glioblastoma patients. Ann Oncol 2009;20:175-181. https://doi. org/10.1093/annonc/mdn548

8. Gilbert MR, Wang M, Aldape KD, et al. Dose-dense temozolomide for newly diagnosed glioblastoma: a randomized phase III clinical trial. J Clin Oncol 2013;31:4085-4091. https://doi.org/10.1200/ JCO.2013.49.6968

9. Keskin E, Elmas Ö, Aydin HA, Şimşek K, Gün E, Kalaycı M. Glioblastome multiforme epidemiyolojisi, tedavi seçenekleri ve sağ kalım süresi: retrospektif tek merkezli çalışma. Batı Karadeniz Tıp Dergisi 2021;5:248-255. https://doi.org/10.29058/mjwbs.875041

10. Khasraw M, Lassman $A B$. Advances in the treatment of malignant gliomas. Curr Oncol Rep 2010;12:26-33. https://doi.org/10.1007/s11912-009-0077-4

11. Chien $\mathrm{CH}$, Hsueh WT, Chuang JY, Chang KY. Dissecting the mechanism of temozolomide resistance and its association with the regulatory roles of intracellular reactive oxygen species in glioblastoma. $\mathrm{J}$ Biomed Sci 2021;28:18. https://doi.org/10.1186/s12929-02100717-7 
12. Tahara T, Shibata T, Yamashita H, et al. Promoter methylation status of multidrug resistance 1 (MDR1) gene in noncancerous gastric mucosa correlates with Helicobacter Pylori infection and gastric cancer occurrence. Cancer Invest 2010;28:711-716. https:// doi.org/10.3109/07357907.2010.483505

13. Ambudkar SV, Kimchi Sarfaty C, Sauna ZE, Gottesman MM. P-glycoprotein: from genomics to mechanism. Oncogene 2003;22:7468-7485. https:// doi.org/10.1038/sj.onc. 1206948

14. Chen CJ, Clark D, Ueda K, Pastan I, Gottesman MM, Roninson IB. Genomic organization of the human multidrug resistance (MDR1) gene and origin of P-glycoproteins. J Biol Chem 1990;265:506-514.

15. Takanishi K, Miyazaki M, Ohtsuka M, Nakajima $\mathrm{N}$. Inverse relationship between P-glycoprotein expression and its proliferative activity in hepatocellular carcinoma. Oncology 1997;54:231-237. https://doi. org/10.1159/000227694

16. Scotlandi K, Manara MC, Serra M, et al. The expression of P-glycoprotein is causally related to a less aggressive phenotype in human osteosarcoma cells. Oncogene 1999;18:739-746. https://doi.org/10.1038/ sj.onc. 1202330

17. Goldstein LJ, Galski H, Fojo A, et al. Expression of a multidrug resistance gene in human cancers. J Natl Cancer Inst 1989;81:116-124. https://doi.org/10.1093/ jnci/81.2.116

18. Pastan I, Gottesman M. Multiple-drug resistance in human cancer. N Engl J Med 1987;316:1388-1393. https://doi.org/10.1056/NEJM198705283162207

19. Matsumoto T, Tani E, Kaba K, et al. Amplification and expression of a multidrug resistance gene in human glioma cell lines. J Neurosurg 1990;72:96-101. https:// doi.org/10.3171/jns.1990.72.1.0096

20. Podolski Renić A, Jadranin M, Stanković T, et al. Molecular and cytogenetic changes in multi-drug resistant cancer cells and their influence on new compounds testing. Cancer Chemother Pharmacol 2013;72:683-697. https://doi.org/10.1007/s00280-0132247-1

21. Qiu YY, Mirkin BL, Dwivedi RS. MDR1 hypermethylation contributes to the progression of neuroblastoma. Mol Cell Biochem 2007;301:131-135. https://doi. org/10.1007/s11010-006-9404-3

22. Yegnasubramanian S, Kowalski J, Gonzalgo ML, et al. Hypermethylation of $\mathrm{CpG}$ islands in primary and metastatic human prostate cancer. Cancer Res 2004;64:1975-1986. https://doi.org/10.1158/00085472.can-03-3972

23. Bastian PJ, Palapattu GS, Yegnasubramanian S, et al. $\mathrm{CpG}$ island hypermethylation profile in the serum of men with clinically localized and hormone refractory metastatic prostate cancer. J Urol 2008;179:529-534. https://doi.org/10.1016/j.juro.2007.09.038
24. Ellinger J, Bastian $\mathrm{PJ}$, Jurgan $\mathrm{T}$, et al. CpG island hypermethylation at multiple gene sites in diagnosis and prognosis of prostate cancer. Urology 2008;71:161167. https://doi.org/10.1016/j.urology.2007.09.056

25. von Bossanyi P, Diete S, Dietzmann K, Warich Kirches M, Kirches E. Immunohistochemical expression of P-glycoprotein and glutathione S-transferases in cerebral gliomas and response to chemotherapy. Acta Neuropathol 1997;94:605-611. https://doi.org/10.1007/ s004010050756

26. Yokogami K, Kawano H, Moriyama T, et al. Application of SPET using technetium-99m sestamibi in brain tumours and comparison with expression of the MDR-1 gene: is it possible to predict the response to chemotherapy in patients with gliomas by means of 99mTc-sestamibi SPET? Eur J Nucl Med 1998;25:401409. https://doi.org/10.1007/s002590050238

27. Abe T, Mori T, Wakabayashi Y, et al. Expression of multidrug resistance protein gene in patients with glioma after chemotherapy. J Neurooncol 1998;40:1118. https://doi.org/10.1023/a:1005954406809

28. Tomar MS, Kumar A, Srivastava C, Shrivastava A. Elucidating the mechanisms of Temozolomide resistance in gliomas and the strategies to overcome the resistance. Biochim Biophys Acta Rev Cancer 2021;1876:188616. https://doi.org/10.1016/j. bbcan.2021.188616

Ethics committee approval: The study was conducted after approval by the Clinical Ethical Committee of Ankara University (approval no: 01-14-14 and date: 13 Jan 2014).

\section{Authors' contributions to the article}

Y.E.G., E.B., M.T. and H.C.U have constructed the main idea and hypothesis of the study. Y.E.G., E.B., A.K., V.Y., F.T. and B.T. they developed the theory and edited the material and method section. Y.E.G., A.K., D.G. and M.T. have done the evaluation of the data in the results section. Discussion section of the article. Written by Y.E.G. and H.C.U. reviewed, corrected and approved. In addition, all authors discussed the entire study and approved the final version.

This study was partially presented as a poster at the Personalized Medicine Conference set for May 18-20, 2016 in Tübingen, Germany. 